\title{
Significant Shift of Ambient Night-Time Air Temperature during Rice Growing Season in Major US Rice States
}

\author{
Kharla Mendez ${ }^{1}$, M. Arlene Adviento-Borbe ${ }^{2 *}$, Argelia Lorence ${ }^{1}$, Harkamal Walia ${ }^{3}$ \\ ${ }^{1}$ Department of Chemistry and Physics, Arkansas State University, Jonesboro, AR, USA \\ ${ }^{2}$ Delta Water Management Research Unit, United States Department of Agriculture-Agricultural Research Service, Jonesboro, \\ Arkansas, USA \\ ${ }^{3}$ Department of Agronomy and Horticulture, University of Nebraska-Lincoln, Lincoln, Nebraska, USA \\ Email: *arlene.advientoborbe@usda.gov
}

How to cite this paper: Mendez, K., Adviento-Borbe, M. A., Lorence, A., \& Walia, H. (2021). Significant Shift of Ambient Night-Time Air Temperature during Rice Growing Season in Major US Rice States. American Journal of Climate Change, 10, 134-151.

https://doi.org/10.4236/ajcc.2021.101006

Received: November 10, 2020

Accepted: March 28, 2021

Published: March 31, 2021

Copyright ( 2021 by author(s) and Scientific Research Publishing Inc. This work is licensed under the Creative Commons Attribution International License (CC BY 4.0).

http://creativecommons.org/licenses/by/4.0/

(c) (i) Open Access

\begin{abstract}
Heat stress studies in rice (Oryza sativa sp.) under extreme weather scenarios generally use constant temperatures to influence the crop responses without relation to actual weather changes. These heat stress studies may have limited implications for future crop yields because elevated temperatures are not based on local temperature fluctuations. This study investigated the night-time air temperature pattern and assessed the status and reliability of available weather station data in four major rice growing states; Arkansas (AR), California (CA), Louisiana (LA) and Texas (TX) using four public weather station databases. Hourly and daily night-time air temperatures from 20:00 to 06:00 were obtained from 1940 to 2018 during the rice growing period. During the 67-year period, a significant increase of $1.12^{\circ} \mathrm{C}$ and $0.53^{\circ} \mathrm{C}$ in seasonal night air temperature occurred in CA and $\mathrm{AR}(P \leq 0.001)$ while LA and TX showed minimal to no increase in night air temperature. Across all rice states and years, night air temperature fluctuations ranged between $\pm 0.2^{\circ} \mathrm{C}$ and $\pm 4^{\circ} \mathrm{C}$ with the greatest occurred in $\mathrm{CA}\left(2.9^{\circ} \mathrm{C}\right)$ and $\mathrm{AR}\left(4.5^{\circ} \mathrm{C}\right)$. Mean night-time air temperature across all states ranged from $22.6^{\circ} \mathrm{C}$ to $29.5^{\circ} \mathrm{C}$ with a rate of increase of $0.01^{\circ} \mathrm{C}$ to $0.02^{\circ} \mathrm{C}$ per year since 1941 . Due to a relatively smaller spatial dataset (from 1941-2018), trend analyses for AR, TX and LA showed modest bias with root mean square errors (RMSE) of $0.5^{\circ} \mathrm{C}$ to $1.1^{\circ} \mathrm{C}$ of absolute mean temperature across all locations. Results in this study showed seasonal night-time air temperature change occurred in some major US rice producing states during the last 67-years. This study highlights the need for more weather stations near agricultural farms to reliably derive actual temperature patterns in the rice growing regions.
\end{abstract}




\section{Keywords}

Night-Time Air Temperature, Rice, Climate Variability, Weather Database, US Rice States

\section{Introduction}

The US is the fourth largest rice exporter in the world which is in part due to intensive production and the highest-yielding rice agroecosystems (FAOSTAT, 2015; Childs, 2019). Rice is an important economic crop in the US, with average national production of $\$ 371$ per ha (McBride et al., 2018). Among the US major crops produced, rice has the highest average return on investment (USDA-NASS, 2016). The projected total rice export from 2019-2020 is 95.0 million hundredweight (cwt) (Childs, 2019). Major US rice producing states include Arkansas, California, Louisiana, Mississippi, Missouri and Texas with CA being the highest yielding and AR being the largest harvested areas in the country (USDA, 2018b). Total rice production in the US increased by $128 \%$ between 1960 and 2015 with the highest national mean yield reported in 2013 at $8617 \mathrm{~kg} \cdot \mathrm{ha}^{-1}$ for 1 million ha (USDA-NASS, 2016). These remarkable grain yield increases were driven by increased adoption of high yielding, fertilizer efficient, and disease-insect-resistant rice varieties and improved agronomic practices (i.e. irrigation, tillage). It has been projected that rice yield must increase at a rate of $1.2 \%-2.4 \%$ from its current rate during the next decade to meet the future demand (Grassini et al., 2013). In an effort to sustain future US rice production, cropping systems will require significant yield gains per unit land area while conserving natural resources and reducing environmental degradation.

Initiatives for improving rice production system have been developed to meet the country's increasing rice demand (Batres-Marquez et al., 2009; US Census 2011). Emerging strategies to increase grain yield potential include commercialization of hybrid rice, improved water management, smart fertilization, and stepped-up extension activities (McBride et al., 2018). While advancing rice production systems have been realized in the US for potential rice yield gains, crop production is highly impacted by weather fluctuations. One of the climatic factors affecting rice yields is the increasing air temperature. Specifically, the frequency of warm nights has increased for the past 60 years (Donat et al., 2013). It has been reported that each $1^{\circ} \mathrm{C}$ increase in night-time air temperature during the dry growing season led to $10 \%$ drop in rice yield (Peng et al., 2004). Other studies reported yield penalties due to high night-time air temperature (HNT) varied from $8 \%$ to 95\% (Mohammed \& Tarpley, 2009b; Mohammed \& Tarpley, 2010; Zhang et al., 2013; Bahuguna et al., 2017). Differences in yield reduction were attributed to the rice varieties used and air temperature thresholds during the experiment. Overall, these reports provided evidence that HNT stress negatively impacts rice production. 
Studies indicated that reduction in grain yield due to HNT is associated with lower spikelet fertility (Mohammed \& Tarpley, 2010), lower percent pollen germination (Mohammed \& Tarpley, 2009a), and increased night respiration rates (Mohammed \& Tarpley, 2009b; Bahuguna et al., 2017). HNT also had direct effects on panicle development and panicle weight (Kanno \& Makino, 2010). The starch content of rice grains was relatively lower among selected sensitive and high yielding rice varieties (Bahuguna et al., 2017). Grain quality was also affected under HNT through the development of chalky kernels, decreased grain weight and its dimensions (Cooper et al., 2008; Morita et al., 2005, Lanning et al., 2011; Bahuguna et al., 2017). The rationale of many studies behind understanding HNT impacts on grain yield has been mostly anchored on predicted global temperature trends based on climate model scenarios. According to IPCC's current predictions, the global temperature may continue rising by $0.2^{\circ} \mathrm{C}$ per decade (IPCC, 2018).

Multiple weather databases are available for assessing temperature patterns across the global landscape. These weather databases (i.e. NOAA-NCDC, NASA-POWER) provide complete coverage of terrestrial surfaces with weather information derived typically from global computer models, remotely sensed surface satellite data, interpolated or actual weather station data. Despite various weather data sources and the need to assess climate variability effects on crop production, there have been no reports on the actual deviations of seasonal night-time air temperature during rice growth stages (i.e. R4 or flowering stage) that are critical for yield and grain quality (Counce et al., 2000). Studies on temperature patterns of specific regions during crop growth are rarely calculated and validated against recorded daily temperature data from well-maintained weather stations. In the study of heat stress, air temperatures are often set based on assumptions or estimations that do not have a ground basis for a specific region. Actual air temperature trends based on weather station data in a particular location or farm is important to agronomist, breeders and researchers to accurately design studies that properly address the level of heat stress in rice. Additionally, the use of field-based data accurately improves technological advancement in rice breeding and farming systems for current and future climate. To address local temperature changes that may influence rice yields, this study aimed to calculate the prevalent seasonal night-time air temperature in the four major US rice producing states during rice growth period. In addition, we assessed the accuracy of simulated air temperature from weather databases using actual air temperature data reported in weather stations. The overarching goal of this study was to provide evidence of significant trends in seasonal night air temperature changes in major US rice-growing regions.

\section{Materials and Methods}

\subsection{Weather Data Sources}

Air temperature data used in this study were obtained from meteorological sta- 
tions that have historical records of regional and/or global weather data. Temperature data were taken from 1) National Aeronautics and Space Administration-Prediction of Worldwide Energy Resources database (NASA-POWER), 2) the National Oceanic and Atmospheric Administration-National Climatic Data Center (NOAA-NCDC), 3) California Irrigation Management Information Systems database (CIMIS) and 4) Integrated Agricultural Information and Management System Climatic database (iAIMS) (Table 1). These weather databases are publicly accessible, cover diverse spatial and temporal resolution, and are widely used by researchers for studying the effects of climate change in food systems (van Wart et al., 2013; Morell et al., 2016; Mourtzini et al., 2017). The NASA-POWER database is produced by the NASA Langley Research Center (LaRC) POWER Project funded through the NASA Earth Science/Applied Science Program. Air temperature in the NASA-POWER database is retrieved on a daily basis at $1-2 \mathrm{~km}^{2}$ resolution and derived from satellite observations coupled with NASA's Modern Era Retro-analysis for Research and Applications (MERRA-2), an integrated system of models (Goddard Earth Observing System Model) informed by data from modern satellite, ground stations and other sources. In contrast, the NOAA-NCDC database is a collection of daily historical observations from 40,000 weather stations around the world, in which data underwent several quality assurance procedures (NCDC, 2011). Most of these weather stations are located in airports or cities; hence, observations cannot accurately and reliably be used for agricultural applications. In contrast, CIMIS and iAIMS are weather databases that retrieved meteorological data from stations located mostly in agricultural areas. CIMIS is a program unit in the Water Use and Efficiency Branch, Division of Regional Assistance of the California

Table 1. Description of weather data collected and open-accessed climate databases used in this study.

\begin{tabular}{|c|c|c|c|c|c|c|}
\hline $\begin{array}{l}\text { Weather } \\
\text { database }^{1}\end{array}$ & Classification & Data source & $\begin{array}{c}\text { Terrestrial } \\
\text { scope }\end{array}$ & Year & $\begin{array}{c}\text { Time } \\
\text { interval }\end{array}$ & $\begin{array}{c}\text { Reported } \\
\text { temperature } \\
\text { variables }\end{array}$ \\
\hline NOAA-NCDC & Point-based & $\begin{array}{l}\text { Weather } \\
\text { stations }\end{array}$ & Global & 1940-present & Hourly & $\begin{array}{c}\text { Minimum, } \\
\text { maximum, } \\
\text { average }\end{array}$ \\
\hline NASA-POWER & $\begin{array}{c}\text { Gridded data, } \\
\text { point-based }\end{array}$ & $\begin{array}{c}\text { Interpolated } \\
\text { and generated } \\
\text { from weather } \\
\text { stations }\end{array}$ & Global & 1981-present & Daily & $\begin{array}{l}\text { Minimum, } \\
\text { maximum, } \\
\text { average }\end{array}$ \\
\hline CIMIS & Point-based & $\begin{array}{l}\text { Weather } \\
\text { stations }\end{array}$ & Regional & 1982-present & Hourly & Average \\
\hline iAIMS & Point-based & $\begin{array}{l}\text { Weather } \\
\text { stations }\end{array}$ & Global & 1940-present & $\begin{array}{l}\text { Daily, } \\
\text { Hourly }\end{array}$ & $\begin{array}{c}\text { Minimum, } \\
\text { maximum, } \\
\text { average }\end{array}$ \\
\hline
\end{tabular}

${ }^{1} N O A A-N C D C$, National Oceanic and Atmospheric Administration - National Climatic Data Center; NASA-POWER, National Aeronautics and Space Administration - Prediction of Worldwide Energy Resources database; CIMIS, California Irrigation Management Information Systems database; iAIMS, Integrated Agricultural Information and Management System Climatic database. 
Department of Water Resources, and has 145 automated weather stations in California (https://cimis.water.ca.gov/). CIMIS was developed in 1982 and designed to assist crop growers and irrigators in managing their water resources more efficiently (CIMIS, 2020). The iAIMS climatic database is part of integrated soil, climate, and crop databases developed in 2007 by the Agroecosystems Research Group at the Texas A \& M University Agricultural Research and Extension Center in Beaumont, Texas (Yang et al., 2010). The iAIMS climatic database is an archive of daily historical data obtained from five weather data sources namely: 1) Texas A \& M University, Crop Weather Program Weather Station Network at Corpus Christi, TX (https://beaumont.tamu.edu/ClimaticData/), 2) NOAA's National Weather Service Aviation Weather, Cooperative Observer Program (COOP) network, 3) Texas A\&M University, Meteorological Aviation Report (METAR) Department of Atmospheric Sciences, 4) NCDC Global Surface Summary of Day Data that is based on data exchanged under the World Meteorological Organization (WMO) World Weather Watch Program according to WMO Resolution 40 (Cg-XII), and 5) NOAA NCDC Climate data online (https://www.ncdc.noaa.gov/cdo-web/) (Yang et al., 2010). The iAIMS is a web-based interface that summarizes climatic data, soil and cropland databases to provide dynamic access to consolidated and filtered data for studying cropping systems performance and management. It consists of climatic data from over 25,000 weather stations worldwide and serves as a support tool in data retrieval of information without duplication. This study used the climatic data component of iAIMS which consisted of temperature data from weather stations in TX.

In this study, hourly and daily air temperature data in rice producing states were mined from NOAA-NCDC, CIMIS and iAIMS climatic databases (Table 1). Air temperature data from NASA-POWER database were also used to compare simulated temperature data and observed weather station data collected from NOAA-NCDC, CIMIS, iAIMS databases. Air temperature data in these databases were archived on an hourly to daily basis and at high spatial resolution: 10 to $110 \mathrm{~km}$ $\left(\mathrm{NOAA}-\mathrm{NCDC}\right.$ ) and $0.5^{\circ} \times 0.5^{\circ}$ latitude and longitude global grid (NASAPOWER). In the analysis of night-time air temperature pattern, rice growing counties were identified in the rice producing states using the USDA-NASS crop website (http://www.nass.usda.gov/Surveys/Guide\%20_to_NASS_\%20Surveys/Crops_\%20S tocks/index.php). More than 70 years of air temperature data were available for all rice states (1941-2018). The longest consecutive years available from NOAA-NCDC database for air temperature were CA. In order to maintain unbiased analysis of weather pattern, we considered equivalent time series with $>20$ years of data archived across all states. Air temperature parameters such as maximum, minimum, and mean air temperature data were not always available in all weather station databases (Table 1). In order to be accurate with long-term weather data analysis and because minimum air temperature data were not consistently monitored and recorded in all databases during the 76-year period, we used average hourly air temperature for all rice states and years in the trend analysis of air temperature. 


\subsection{Boundary Conditions}

To calculate and summarize mean ambient night-time air temperature, the data retrieval was limited by the time of the day, month, and location. Air temperature data were collected from 20:00 to 06:00 within the rice growing period. The time of observation was limited to 10-hour period to capture the night field condition. According to Bahuguna et al. (2017), important physiological processes such as respiration which influence rice grain filling occurred at night. In this study, rice growing months were May to September for all locations and states. While flowering and reproductive stages are critical part in rice growth, under field growing condition, changes in mean air temperature do not occur only during specific period of growth but throughout the growing season. Grain yield of rice is not only affected by heat stress at those growth stages but mainly affected by crop and grain establishment that is influenced by heat stress at the beginning of the growing season and near maturity. We used the rice growing duration to capture the historical pattern of air temperature to which rice crop is exposed. Also, aiming for higher yield depends on increasing total biomass. According to Peng et al. (2004), total crop biomass is determined mainly by crop photosynthesis and respiration losses, and both are sensitive to temperature.

Four US rice states included in this study were: CA, AR, LA and TX accounting for about $90 \%$ of US rice area and production (USDA, 2018a). California is located in the US western region while TX, LA and AR are located in the South (Figure 1). Air temperature data from Mississippi (MS) and Missouri (MO) were not considered because of total rice harvested areas comprised only $5.7 \%$

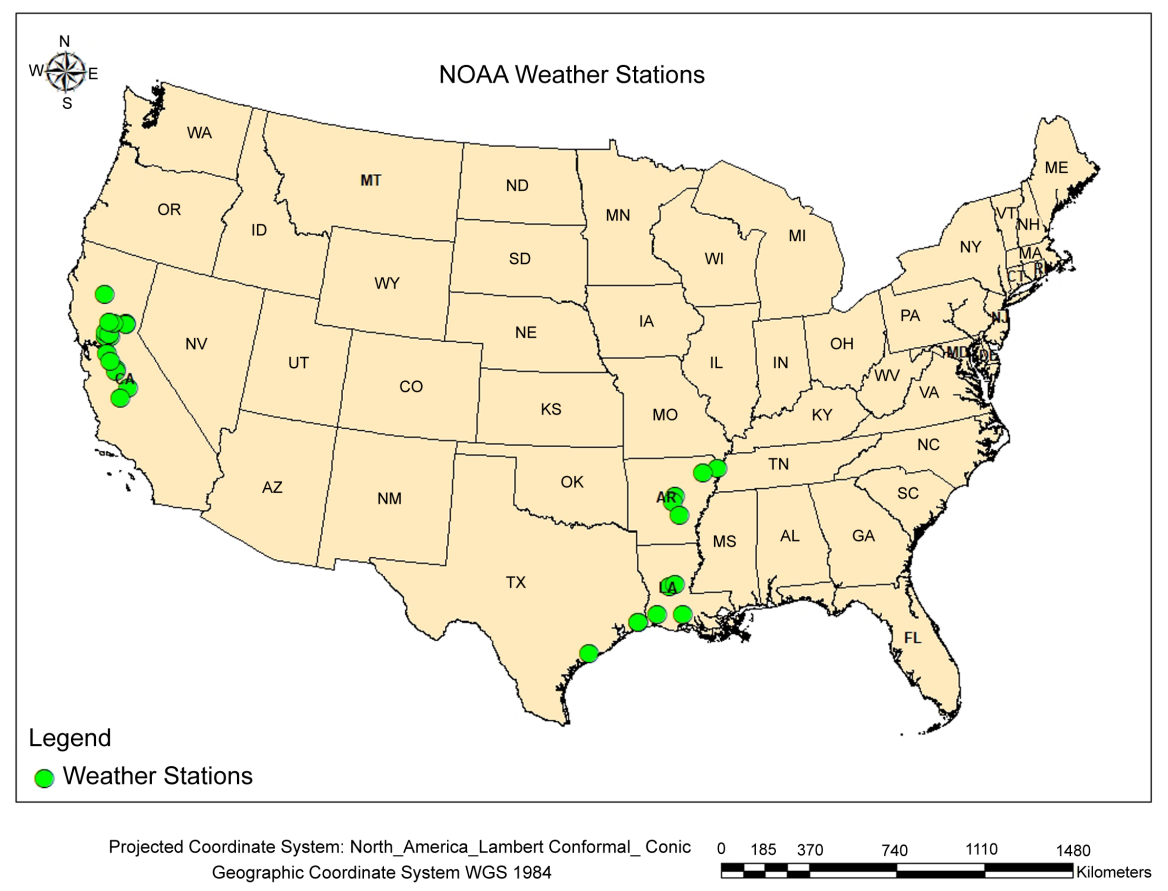

Figure 1. Location map of weather stations in California, Arkansas, Louisiana and Texas, US used in this study. 
and $6.5 \%$ of the total US harvested ricearea, respectively. Also, available air temperature weather station data in these two states had $<20$ years record. According to USDA-NASS (2018c), AR covered approximately $80 \%$ of the total rice areas in US Delta Region. Overall, air temperature from 1940 to 2018 was retrieved from 23 locations across four major rice states (CA, AR, LA, TX), resulting in ca. (about) $>1200$ observations per site per year. For those sites that generated incomplete time-series due to erroneous entries or missing values $(24 \%$ to $50 \%$ ) we did not perform gap-filling or interpolation from air temperature from the two nearest weather stations to the weather station being estimated. To achieve real-time calculation of air temperature pattern, those sites-years with missing values were excluded in the trend analysis of night-time air temperature for each state.

\subsection{Data Analysis}

Average night-time air temperature was calculated from $1^{\text {st }}$ May to $30^{\text {th }}$ September from 20:00 to 06:00 for each location-state-year, separately for NOAA-NCDC, CIMIS and iAIMS weather station database and the NASA-POWER database. In each of the four US rice-growing states across all years and locations, linear regression was used to identify if a significant increase in night-time air temperature occurred in the past seven decades (SYSTAT, 2013). The air temperature data from NOAA-NCDC were regarded as the dependent variable while time in unit of the year was considered as the independent variable. The slope of regression was tested for significant difference at $P<0.05$ level. We explored the accuracy of the interpolated air temperature from NASA-POWER database, a widely used weather database. Using the same location coordinates and years, simulated air temperature from NASA-POWER database was compared to actual air temperature data from active weather stations (NOAA-NCDC, CIMIS, iAIMS) in each rice-growing state. For a given state, accuracy and biases between interpolated and observed air temperature were assessed with the absolute mean error $(\mathrm{ME})$, root mean square error (RMSE), and coefficient of variation $(\mathrm{CV})$. These parameters were calculated as follows:

$$
\begin{gathered}
\mathrm{ME}=\frac{\sum_{i=1}^{n}\left(\text { Temp }_{i}^{P}-\text { Temp }_{i}^{O}\right)}{n} \\
\mathrm{RMSE}=\sqrt{\frac{\sum_{i=1}^{n}\left(\text { Temp }_{i}^{P}-\text { Temp }_{i}^{O}\right)^{2}}{n}} \\
\mathrm{CV}=\frac{\sigma}{\mu}
\end{gathered}
$$

where $n$ is number of site-year, $\operatorname{Temp}_{i}^{O}$ is air temperature from active weather station for the $i$ th site-year whereas $\operatorname{Temp}_{i}^{P}$ is the simulated/calculated night-time air temperature. The $\sigma$ and $\mu$ are standard deviation and mean, respectively, of interpolated or observed air temperature. The mean error, ME, measures the mean magnitude and sign of the bias with air temperature from predicted or 
weather station data. Root mean square error, RMSE, measures the degree of agreement between weather data sources and quantifies average error on a relative basis compared to actual weather station data. CV measures the relative variability in a distribution.

\section{Results and Discussion}

\subsection{Comparison between Estimated and Measured Air Temperature}

The ability to accurately estimate temperature fluctuations under wide range of cropping environments depends on credible calculations and sources of weather data. In this study, hourly night-time air temperature data for some rice counties were fundamentally challenging to summarize due to daily time stamp were available for long-term weather data. In this study, we used temperature data from weather stations that reported hourly night air temperature to calculate changes in night air temperature. Prior to temperature trend analysis, we assessed the accuracy of night-time air temperature datasets from NASA-POWER database. The simulated datasets were compared to average daily measured night-time air temperature data from NOAA-NCDC, CIMIS and iAIMS databases. NASA-POWER air temperature datasets were different for most parts of US rice regions (CA, AR, LA) and deviations from measured values were consistent from 1981 to 2018 (Figure 2 and Figure 3). For CA and AR, NASA-POWER predicted values were approximately $2^{\circ} \mathrm{C}-4^{\circ} \mathrm{C}$ lower compared to NOAA-NCDC's observed values. In contrast, average hourly air temperature differences of roughly $<1^{\circ} \mathrm{C}$ were observed in $\mathrm{LA}$ and $\mathrm{TX}$ datasets and values between
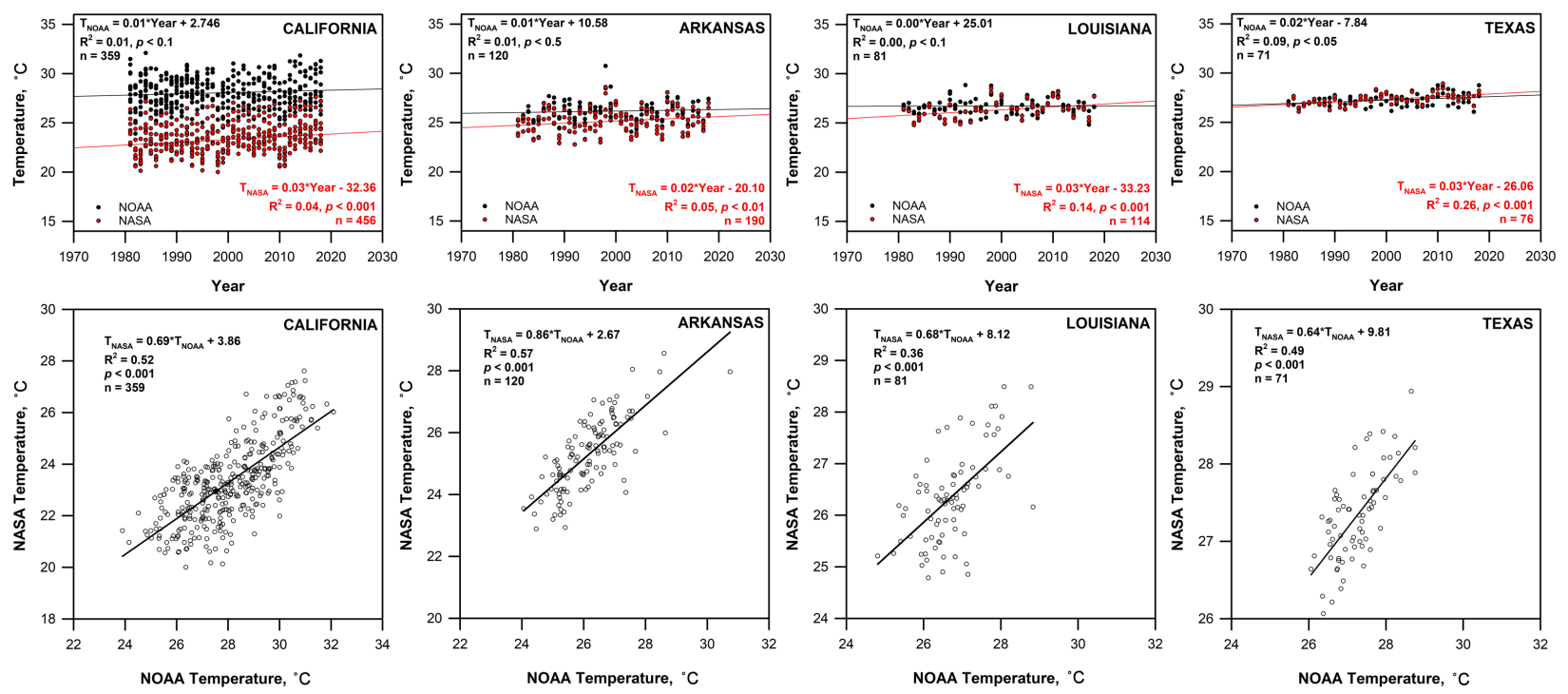

Figure 2. Average night-time air temperature data (top 4 scatterplots) from the National Oceanic and Atmospheric Administration-National Climatic Data Center database (O NOAA), and National Aeronautics and Space Administration-Prediction of Worldwide Energy Resources database (O; NASA-POWER) and relationship of night-time air temperature data (bottom 4 scatterplots) from NOAA and NASA-POWER databases in all study states during 1980 to 2018 period. 

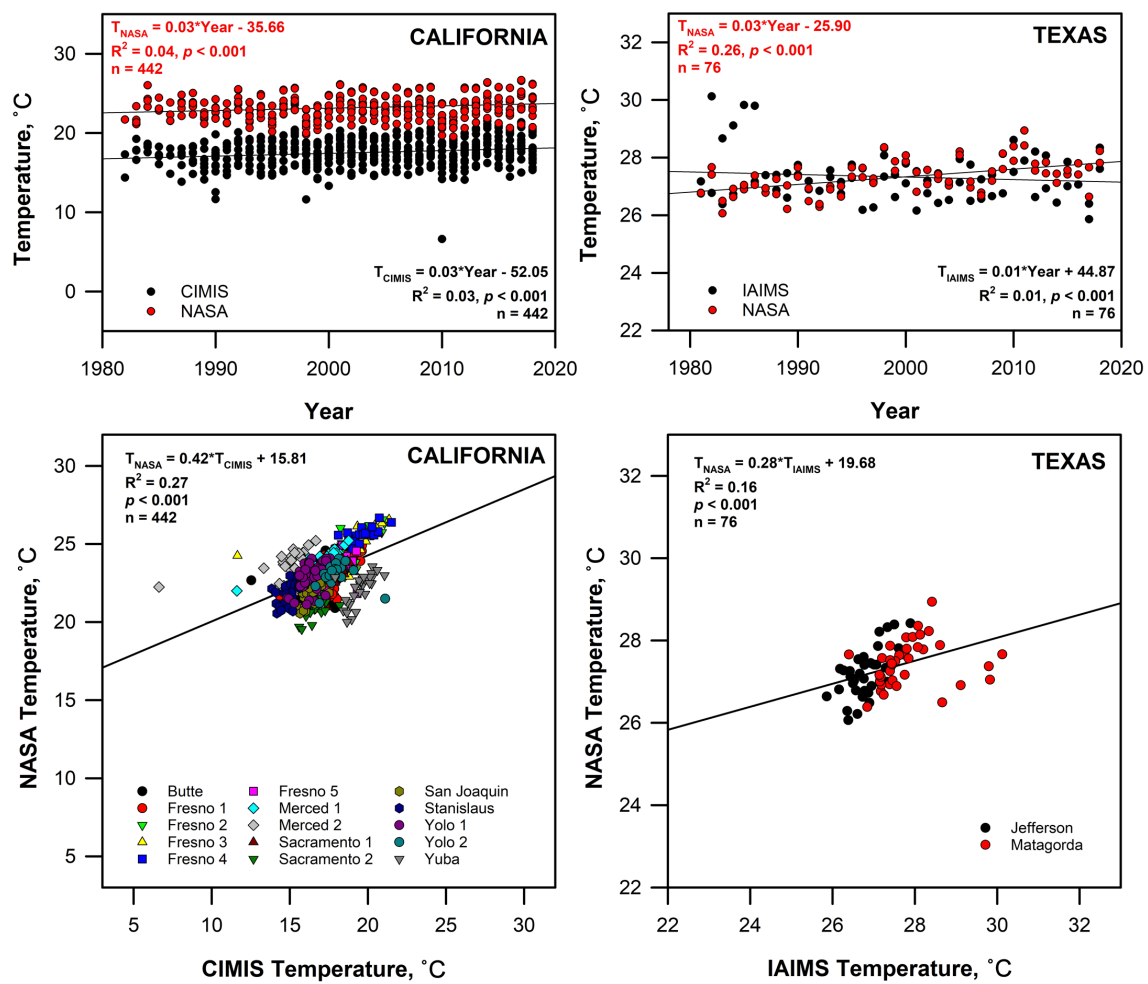

Figure 3. Average night-time air temperature data (top left scatterplot) from the National Aeronautics and Space Administration - Prediction of Worldwide Energy Resources database ( ; NASA-POWER) and California Irrigation Management Information Systems ( ; CIMIS) database (top left scatterplot), Integrated Agricultural Information and Management System Climatic database (O; iAIMS) top right scatterplot) and relationship of night-time air temperature data (bottom 2 scatterplots) from NASA-POWER, CIMIS and iAIMS databases during 1980 to 2018 period. Different symbols in bottom 2 scatterplots show various state counties within each state where air temperature data were retrieved.

predicted and observed tended to close the gap from 1980 to 2018 (Figure 2). The total number of observations in LA and TX datasets was 33\% to $80 \%$ lower relative to observations used in CA and AR datasets (Figure 2). Deviations of predicted night air temperature from NASA-POWER database to night air temperature weather station data from various weather station sources were apparent (Figure 2 and Figure 3). To illustrate, predicted night air temperature in CA using NASA-POWER dataset underestimated night air temperature from NOAA-NCDC weather database (Figure 2). However, this relationship was reversed when NASA-POWER air temperature was compared to air temperature datasets from CIMIS database (Figure 3). The observed difference between NOAA-NCDC and CIMIS weather station data was probably due to the location of weather station managed by both organizations. NOAA-NCDC weather stations are generally located near airports or cities, while CIMIS weather stations are located near agricultural farms. These results showed relatively large uncertainties and a strong bias towards weather stations location and the total number of temperature data points for a given station. Overall, our results showed inconsistencies in predicting air temperature data and historical temperature 
trends when using the NASA-POWER data for night air temperature trend analysis in some US rice states.

\subsection{Air Temperature from Weather Stations}

The NOAA-NCDC database was used in the analysis of night-time air temperature patterns. All four states had weather stations with $>20$ years of recorded hourly air temperature and available for public use (Table 2). Following an exhaustive weather data collection, air temperature data were retrieved from $12,5,4$, and 2 weather stations located near rice counties with 20 to 67 total recorded years for CA, AR, LA and TX, respectively (Table 2). California had the most number of observed air temperature data points due to weather stations availability with $>20$ years of data archived compared to the other three states (Table 2). Texas had the least number of historical air temperature data points on record with stations mostly located in the southeastern region of the state. Arkansas and LA had temperature data approximately $30 \%$ of CA's temperature data owed to relatively fewer weather stations were available near rice counties.

Despite the extensive recorded years coverage of temperature data across rice states, very few well-maintained weather stations were located inside major rice producing counties. To illustrate these points, AR and LA are the largest southern rice states with total harvested rice area of 508,287 ha and 120,373 ha but there were only 4 to 5 weather stations with long-term data archived (Table 2). Several major producing rice counties within each state had no long-term air temperature data. This was true for Poinsett and Arkansas Counties in AR, Acadia and Jefferson Counties in LA, Wharton County in TX and Colusa and Sutter Counties in CA. Most weather stations found in all states were operating near

Table 2. Description of rice counties and weather station datasets used in air temperature analysis.

\begin{tabular}{|c|c|c|c|c|c|c|}
\hline State & $\begin{array}{l}\text { Total } \\
\text { number } \\
\text { of rice } \\
\text { counties }\end{array}$ & $\begin{array}{c}\text { Total rice } \\
\text { harvested } \\
\text { area, ha }\end{array}$ & $\begin{array}{c}\text { Rice county near } \\
\text { weather station } \\
\text { with }>20 \text { years } \\
\text { weather data archives }\end{array}$ & $\begin{array}{c}\text { Total } \\
\text { number of } \\
\text { weather } \\
\text { stations }\end{array}$ & $\begin{array}{l}\text { Range of } \\
\text { total number } \\
\text { of recorded } \\
\text { years }\end{array}$ & $\begin{array}{c}\text { Total } \\
\text { number of } \\
\text { observations }^{\text {used }^{1}}\end{array}$ \\
\hline $\begin{array}{l}\text { California } \\
\text { (CA) }\end{array}$ & 13 & 207,766 & $\begin{array}{l}\text { Fresno, Merced, } \\
\text { Sacramento, San } \\
\text { Joaquin, Stanislaus, } \\
\text { Tehama, Yuba }\end{array}$ & 12 & $33-67$ & $1,111,053$ \\
\hline $\begin{array}{l}\text { Arkansas } \\
\text { (AR) }\end{array}$ & 31 & 508,287 & $\begin{array}{l}\text { Craighead, Jefferson, } \\
\text { Mississippi, Pulaski }\end{array}$ & 5 & $28-57$ & 330,526 \\
\hline $\begin{array}{l}\text { Louisiana } \\
\text { (LA) }\end{array}$ & 16 & 120,373 & Lafayette, Rapides & 3 & $42-56$ & 345,483 \\
\hline $\begin{array}{l}\text { Texas } \\
(\mathrm{TX})\end{array}$ & 13 & 52,609 & Jefferson, Matagorda & 2 & $46-48$ & 181,635 \\
\hline
\end{tabular}

${ }^{1}$ Total number of observations (air temperature data) was computed from the sum of total air temperature data in all locations and recorded years in each state. 


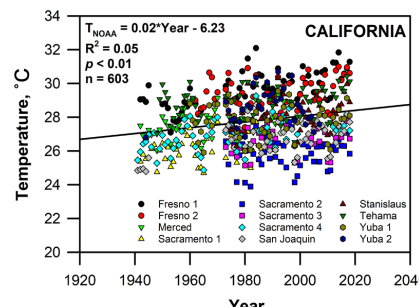

(a)

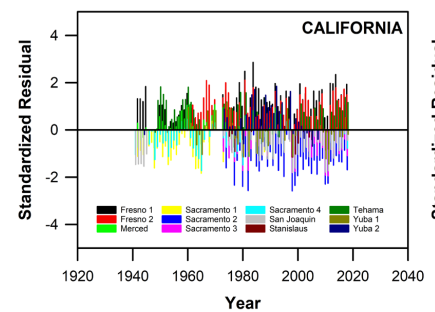

(e)

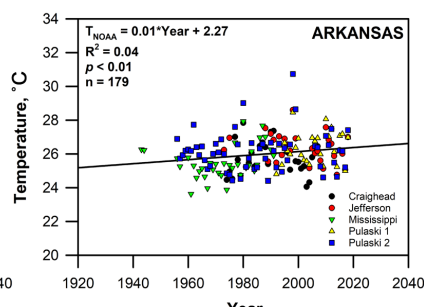

(b)ar
(b)

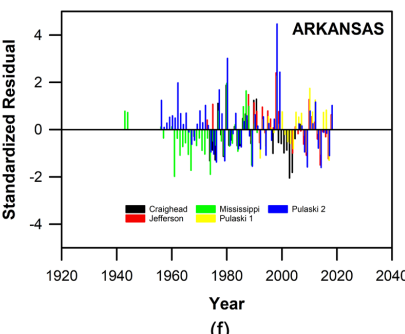

(f)

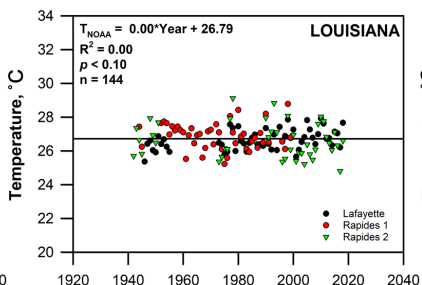

Year
(c)

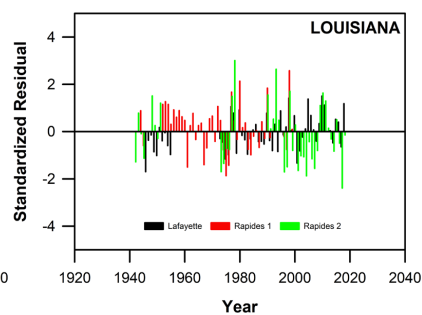

(g)

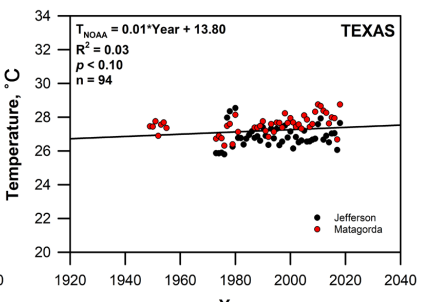

Year
(d)

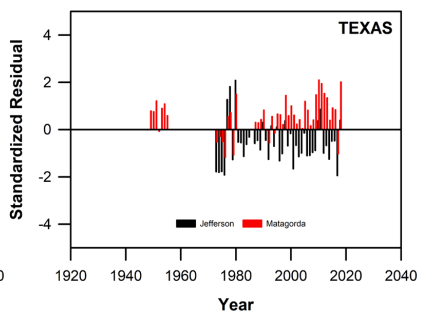

(h)

Figure 4. Average night-time air temperature data from weather stations using the NOAA-NCDC database (top 4 plots) and standardized residuals (bottom 4 plots) during rice growing season in CA (a); AR (b); LA (c); and TX (d) during 1940 to 2018. Standardized residual plots for CA (e); AR (f); LA (g) and TX (h) show deviations of data points from the linear regression line. Colored symbols represent different rice state counties where air temperature data were retrieved. 
weather parameters are commonly used to assess climate change and agricultural-related research such as decision-support tool systems to assist in crop and farm management (i.e. Foley et al., 2005; Lobell et al., 2011; Morell et al., 2016). However, several studies have compared interpolated weather data to actual weather station data and determined weather data simulation accuracy perform when used as input for crop model estimates (Van wart et al., 2013; Mourtzinis et al., 2017). Findings from these studies indicated that simulated weather station data could not replace measured weather data as a basis for field-scale agricultural applications i.e. yield, crop growth stage, water balance. Given the uncertainties of simulated weather data for crop research applications, calculations of night-time air temperature patterns in this study were based only on measured weather station data.

\subsection{Night-Time Air Temperature Pattern in the Four Rice Producing States}

On average, measured night-time air temperature data across all rice growing areas and years were above $23^{\circ} \mathrm{C}$ (Figure 4, Table 3) and ranged from $22.6^{\circ} \mathrm{C}$ to $29.5^{\circ} \mathrm{C}$ during the rice growing period. The magnitude of mean seasonal night-time air temperature was highest in CA and lowest in TX (Figures 3(a)-(d)). Measured night-time air temperature fluctuated between $\pm 0.2^{\circ} \mathrm{C}$ and $\pm 4^{\circ} \mathrm{C}$ in all states with the most frequent in $\mathrm{CA}$ and intense fluctuation occurred in AR (Figures 4(e)-(h)). The minimal intensity of temperature fluctuations occurred in LA (Figure $3(\mathrm{~g})$ ). In all states, the rate of increase of night-time air temperature ranged from $0.01^{\circ} \mathrm{C}$ to $0.02^{\circ} \mathrm{C}$ per year since 1941. During the last 67-year period, night-time air temperature increased by $1.12^{\circ} \mathrm{C}, 0.53^{\circ} \mathrm{C}$, and $0.30^{\circ} \mathrm{C}$ in CA, AR, TX, respectively and no increase was observed in LA $\left(0.0^{\circ} \mathrm{C}\right)$ (Table 3). On average, calculated seasonal night-time air temperature using the NOAA-NCDC weather data were in close agreement with actual seasonal night-time

Table 3. Summary of trend analysis of night-time air temperature during rice growing season in the four major US rice states from 1940 to 2018 period.

\begin{tabular}{|c|c|c|c|c|c|c|c|c|}
\hline \multirow[t]{2}{*}{ Rice state } & \multirow{2}{*}{$\begin{array}{c}\mathrm{ME}^{1} \\
{ }^{\circ} \mathrm{C}\end{array}$} & \multirow{2}{*}{$\begin{array}{c}\mathrm{RMSE}^{2} \\
{ }^{\circ} \mathrm{C}\end{array}$} & \multirow[t]{2}{*}{$\mathrm{CV}^{3}$} & \multicolumn{2}{|c|}{$\begin{array}{l}\text { Measured night-time } \\
\text { air temperature }{ }^{4},{ }^{\circ} \mathrm{C}\end{array}$} & \multicolumn{2}{|c|}{$\begin{array}{l}\text { Calculated night-time } \\
\text { air temperature }{ }^{5},{ }^{\circ} \mathrm{C}\end{array}$} & \multirow{2}{*}{$\begin{array}{c}\text { Calculated } \\
\text { temperature } \\
\text { difference, }{ }^{\circ} \mathrm{C}\end{array}$} \\
\hline & & & & Minimum & Maximum & Minimum & Maximum & \\
\hline $\begin{array}{l}\text { California } \\
\text { (CA) }\end{array}$ & 1.3 & 2.4 & 5.6 & 23.9 & 32.1 & 27.1 & 28.2 & 1.1 \\
\hline $\begin{array}{l}\text { Arkansas } \\
\text { (AR) }\end{array}$ & 0.8 & 1.1 & 4.0 & 23.6 & 30.7 & 25.8 & 26.4 & 0.5 \\
\hline $\begin{array}{l}\text { Louisiana } \\
\text { (LA) }\end{array}$ & 0.6 & 0.6 & 3.0 & 24.8 & 29.1 & 26.7 & 26.7 & 0.0 \\
\hline $\begin{array}{l}\text { Texas } \\
(\mathrm{TX})\end{array}$ & 0.6 & 0.5 & 2.5 & 25.8 & 28.7 & 27.1 & 27.4 & 0.3 \\
\hline
\end{tabular}

${ }^{1} \mathrm{ME}$ : Mean error was calculated using Equation (1). ${ }^{2} \mathrm{RMSE}$ : Root mean square error was calculated using Equation (2). ${ }^{3} \mathrm{CV}$ : coefficient of variations was calculated from Equation (3). ${ }^{4}$ Air temperature observations from weather stations. ${ }^{5}$ Air temperature was calculated using linear regression model. 
air temperature across four states with modest estimation of night air temperature data $\left(\mathrm{ME}=0.6^{\circ} \mathrm{C}\right.$ to $\left.1.3^{\circ} \mathrm{C}\right)$ (Table 3$)$. Similarly, \%RMSE for calculated and observed night-time air temperature based on weather database were $8.68 \%$, $4.21 \%, 2.25 \%$ and $1.83 \%$ for CA, AR, LA, and TX, respectively.

The shift in seasonal night-time air temperature was significant in CA and AR $(P$-level $\leq 0.01)$ while LA and TX had no significant difference $(P$-level $\leq 0.10)$. The overall increase in night-time air temperature in CA was in the range of 2 to 22 times greater than the increase in night-time air temperature in the Southern states (Figure 4). The temperature rise observed in this study was unlikely due to local air pollution, as warming trends are consistent with temperature increases found elsewhere (Pathak et al., 2003; Peng et al., 2004). In fact, temperature increase in CA was consistent with the increase in minimum temperature of $1.13^{\circ} \mathrm{C}$ reported by Peng et al. (2004) during the 25-year period of temperature trend analysis in International Rice Research Institute (IRRI) Farm, Philippines. Lobell and Ortiz-Monasterio (2007) analyzed a 15 to 24-year dataset to determined variation of regional spring wheat yields and temperatures for three irrigated sites in western North America and found that in San Luis-Mexicali Valley of Mexico and in the Imperial Valley of California, historical wheat yields were associated with minimum and maximum temperature but projected responses to maximum temperature were three times larger than minimum temperature. Wheat yields in these regions were reduced by $8 \%$ to $10 \%$ for $1^{\circ} \mathrm{C}$ rise of minimum or maximum temperature based on CERES model simulations.

Unlike in the study of Peng et al. (2004), the magnitude of air temperature increase in this study was based on average night air temperature. Long-term trend analysis for minimum air temperature was not performed in this study due to minimum air temperature data were inconsistently recorded in many weather stations prior to 1980 . Generally, the similar increase in air temperature trends observed in this study and other parts of the globe implicitly assumed that temperature changes occurred in minimum and mean night air temperature in rice growing regions. These results may reflect a strong greenhouse gas-induced warming during the last half of the $20^{\text {th }}$ century. The shift in seasonal night-time air temperature was less evident in the Southern states than in CA (Figures $4(\mathrm{a})-(\mathrm{d}))$. In this case, a possible reason for the small temperature increase is the small number of observations in Southern rice counties relative to observations in CA. The total number of observations was 3 to 6 times lower in southern states than in CA. Another possible reason for the minimal temperature rise is likely due to the weak warming trend of surface air temperature in the Southern region caused by changes in sea surface temperature. Wang et al. (2009) reported that climate trend analysis over the Southern US from 1950 to 2000 showed a slight to no increase in air temperature pattern during late spring and summer seasons and trends were attributed to the decadal climate variability pattern in the Pacific and Atlantic oceans.

Results of this paper confirm the observed warming of global surface air tem- 
perature during the last part of the $20^{\text {th }}$ century (IPCC, 2014; Ray et al. 2015; Hansen et al. 2010; Easterling et al., 1997). According to IPCC (2014), the expected changes in surface air temperature by the end of the $21^{\text {th }}$ century are predicted to be in the range of $0.3^{\circ} \mathrm{C}$ to $4.8^{\circ} \mathrm{C}$. Studies on crop growth models showed that predictions from climate models of significant warming of air temperature might lead to crop yield reductions (Rosenzweig \& Parry, 1994; Wheeler et al., 2000; Lobell et al., 2011). Recent research assessing the potential impacts of high night air temperature on rice yield had focused on constant air temperature treatments that were set to produce significant outcomes (i.e. Tamaki et al., 1989; Cooper et al., 2008; Coast et al., 2019). These studies had, for the most part, treated each trait of rice yield potential without relation to actual changes in air temperature under local rice environments. Although these adaptive experiments provided better understanding of rice growth mechanism and the components of grain yield under a set of constant air temperature thresholds, results may have limited implications for potential future sustainable intensive crop production for a specific region. In order to achieve reliable field crop responses to heat stress, heat/temperature stress thresholds should be based on local temperature difference relative to actual ambient temperature in the region. Accurate representation of field growing temperature reliably identifies cause-effect relationships of rice response tolerance, productivity and heat stress. The information discussed in our paper is often overlooked in climate articles because most authors focused on the data analysis and the validity of mathematical models and algorithms used. With the vulnerability of agriculture to deterioration due to climate change, we need results that have direct use to crop growers, breeders, and researchers which will aid them in developing resilient cultivars and farming systems that will sustain food for current and future human population.

\section{Conclusion}

Results in this study showed seasonal night-time air temperature change occurred in major US rice producing states during the last 67-years. Average seasonal night-time air temperature has ranged from $0.0^{\circ} \mathrm{C}$ to $1.12^{\circ} \mathrm{C}$ with greater fluctuations in CA and AR. While many open-accessed weather databases completely provide climatological data, accuracy and reliability of modeled data to predict local weather patterns relied on capturing variability across specific locations and time. Without the presence of weather stations in major rice counties in the US particularly in the southern states, research on temperature effects or heat stress on crop response remains uncertain, and it may lead to a strong bias towards non-agricultural areas. This study justifies the need to establish more weather stations in agricultural areas with strong emphasis in the US Southern States where frequent and intense weather fluctuations are more likely to happen. Currently, crop growers in some parts of the US have started maintaining their own local weather stations. Local or federal support to implement more 
privately owned weather stations could potentially improve accuracy of weather monitoring for the region. This paper highlights the observed warming of surface air temperature during the last part of the $20^{\text {th }}$ century. Although the overall results of our study occur in relatively small portion of the US agricultural areas, they strongly support the realization that warming of seasonal night air temperature will likely continue in the future. Our study provides direct evidence that air temperature changes varied in specific crop region and representing a constant and estimated growth temperature value to crop-specific region may not accurately and reliably reflect actual crop growing environments.

\section{Acknowledgements}

This work is funded by the Wheat and Rice Center for Heat Resilience (WRCHR; http://wrchr.org/) National Science Foundation Award Number \#1736192. Additional support was provided by the Arkansas Biosciences Institute, Arkansas State University and the Office of National Programs through the HQ 0500 Air Quality funds United States Department of Agriculture, Agricultural Research Services. We also thank Dr. Ahmed Hashem of Arkansas State University for his assistance in mapping rice counties in the US.

\section{Conflicts of Interest}

The authors declare no conflicts of interest regarding the publication of this paper.

\section{References}

Bahuguna, R. N., Solis, C. A., Shi, W., \& Jagadish, S. V. K. (2017). Post-Flowering Night Respiration and Altered Sink Activity Account for High Night Temperature Induced Grain Yield and Quality Loss in Rice (Oryza sativa L.). Physiologia Plantarum, 159, 59-73. https://doi.org/10.1111/ppl.12485

Batres-Marquez, P. S., Jensen, H. H., \& Upton, J. (2009). Rice Consumption in the United States: Recent Evidence from Food Consumption Surveys. Journal of the American Dietetic Association, 109, 1719-1727. https://doi.org/10.1016/j.jada.2009.07.010

California Irrigation Management Information System, CIMIS (2020). CIMIS Publications. https://cimis.water.ca.gov/WSNReportCriteria.aspx

Childs, N. (2019). Rice Outlook, RCS-19K. Washington DC: U.S. Department of Agriculture, Economic Research Service. https://www.ers.usda.gov/publications/pub-details/?pubid=95348

Coast, O., Sebela, D., Quiñones, C., \& Jagadish, S. V. K. (2019). Systematic Determination of the Reproductive Growth Stage Most Sensitive to High Night Temperature Stress in Rice (Oryza sativa). Crop Science, 60, 391-403. https://doi.org/10.1002/csc2.20086

Cooper, N. T. W., Siebenmorgen, T. J., \& Counce, P. A. (2008). Effects of Nighttime Temperature during Kernel Development on Rice Physicochemical Properties. Cereal Chemistry, 85, 276-282. https://doi.org/10.1094/CCHEM-85-3-0276

Counce, P. A., Keisling, T. C., \& Mitchell, A. J. (2000). A Uniform, Objective, and Adaptive System for Expressing Rice Development. Crop Science, 40, 436-443.

https://doi.org/10.2135/cropsci2000.402436x 
Donat, M. G., Alexander, L. V., Yang, H., Durre, I., Vose, R., Dunn, R. J. H., Willett, K. M., Aguilar, E., Brunet, M., Caesar, J., Hewitson, B., Jack, C., Klein, Tank, A. M. G., Kruger, A. C., Marengo, J., Peterson, T. C., Renom, M., Oria Rojas, C., Rusticucci, M., Salinger, J., Elrayah, A. S., Sekele, S. S., Srivastava, A. K., Trewin, B., Villaroel, C., Vincent, L. A., Zhai, P., Zhang, X., \& Kitching, S. (2013). Updated Analyses of Temperature and Precipitation Extreme Indices since the Beginning of the Twentieth Century: The HadEX2 Dataset. Journal of Geophysical Research: Atmospheres, 118, 2098-2118. https://doi.org/10.1002/jgrd.50150

Easterling, D. R., Horton, B., Jones, P. D., Peterson, T. C., Karl, T. R., Parker, D. E., Salinger, J. M., Razuvayev, V., Plummer, N., Jamason, P., \& Folland, C. K. (1997). Maxium and Minimum Temperature Trends for the Globe. Science, 277, 364-367. https://doi.org/10.1126/science.277.5324.364

Foley, J. A., Defries, R., Asner, G. P., Barford, C., Bonan, G., Carpenter, S. R., Stuart Chaplin, F., Coe, M. T., Daily, G. C., Gibbs, H. K., Helkowski, H., Holloway, T., Howard, E. A., Kucharik, C. J., Monfreda, C., Patz, J. A., Prentice, C., Ramankutty, N., \& Synder, P. K. (2005). Global Consequences of Land Use. Science, 309, 570-574. https://doi.org/10.1126/science.1111772

Food and Agriculture Organization Corporate Statistical Database, FAOSTAT (2015). Production Quantities by Country. http://faostat3.fao.org

Grassini, P., Eskridge, K. M., \& Cassman, K. G. (2013). Distinguishing between Yield Advances and Yield Plateaus in Historical Crop Production Trends. Nature Communications, 4, 2918. https://doi.org/10.1038/ncomms3918

Hansen, J., Ruedy, R., Sato, M., \& Lo, K. (2010). Global Surface Temperature Change. American Geophysical Union Journal, 48, RG4004. https://doi.org/10.1029/2010RG000345

Intergovernmental Panel on Climate Change, IPCC (2014). Climate Change 2014: Synthesis Report. In R. K. Pachauri, \& L. A. Meyer (Eds.), Contribution of Working Groups I, II and III to the Fifth Assessment Report of the Intergovernmental Panel on Climate Change (151 p.). Geneva, Switzerland: IPCC.

Intergovernmental Panel on Climate Change, IPCC (2018). Annex IV: Expert Reviewers of the IPCC Special Report on Global Warming of $1.5^{\circ} \mathrm{C}$. In V. Masson-Delmotte, P. Zhai, H.-O. Pörtner, D. Roberts, J. Skea, P. R. Shukla, A. Pirani, W. Moufouma-Okia, C. Péan, R. Pidcock, S. Connors, J. B. R. Matthews, Y. Chen, X. Zhou, M. I. Gomis, E. Lonnoy, T. Maycock, M. Tignor, \& T. Waterfield (Eds.), Global Warming of $1.5^{\circ} \mathrm{C}$. An IPCC Special Report on the Impacts of Global Warming of $1.5^{\circ} \mathrm{C}$ above Pre-Industrial Levels and Related Global Greenhouse Gas Emission Pathways, in the Context of Strengthening the Global Response to the Threat of Climate Change, Sustainable Development, and Efforts to Eradicate Poverty (51 p.). Geneva, Switzerland: World Meteorological Organization.

Kanno, K., \& Makino, A. (2010). Increased Grain Yield and Biomass Allocation in Rice under Cool Night Temperature. Journal of Soil Science and Plant Nutrition, 56, 412-417. https://doi.org/10.1111/j.1747-0765.2010.00473.x

Lanning, S. B., Siebenmorgen, T. J., Counce, P. A., Ambardekar, A. A., \& Mauromoustakos, A. (2011). Extreme Nighttime Air Temperatures in 2010 Impact Rice Chalkiness and Milling Quality. Field Crops Research, 124, 132-136. https://doi.org/10.1016/j.fcr.2011.06.012

Lobell, D. B., \& Ortiz-Monasterio, J. I. (2007). Impacts of Day versus Night Temperatures on Spring Wheat Yields: A Comparison of Empirical and CERES Model Predictions in Three Locations. Agronomy Journal, 99, 469-477. https://doi:10.2134/agronj2006.0209

Lobell, D. B., Schlenker, W., \& Costa-Roberts, J. (2011). Climate Trends and Global Crop 
Production since 1980. Science, 333, 616-620. https://doi.org/10.1126/science.1204531

McBride, W. D., Skorbiansky, S. R., \& Childs, N. (2018). U.S. Rice Production in the New Millenium: Changes in Structure, Practices, and Costs. Economic Information Bulletin Number 202. USDA Economic Research Service. https://doi.org/10.2139/ssrn.3304604

Mohammed, A. R., \& Tarpley, L. (2009a). High Nighttime Temperatures Affect Rice Productivity through Altered Pollen Germination and Spikelet Fertility. Agricultural and Forest Meteorology, 149, 999-1008. https://doi.org/10.1016/j.agrformet.2008.12.003

Mohammed, A. R., \& Tarpley, L. (2009b). Impact of High Nighttime Temperature on Respiration, Membrane Stability, Antioxidant Capacity, and Yield of Rice Plants. Crop Science, 49, 313-322. https://doi.org/10.2135/cropsci2008.03.0161

Mohammed, A. R., \& Tarpley, L. (2010). Effects of High Night Temperature and Spikelet Position on Yield-Related Parameters of Rice (Oryza sativa L.) Plants. European Journal of Agronomy, 33, 117-123. https://doi.org/10.1016/j.eja.2009.11.006

Morell, F. J., Yang, H. S., Cassman, K. G., van Wart, J., Elmore, R. W., Licht, M., Coulter, J. A., Ciampitti, I. A., Pittelkow, C. M., Brouder, S. M., Thomison, P., Lauer, J., Graham, C., Massey, R., \& Grassini, P. (2016). Can Crop Simulation Models Be Used to Predict Local to Regional Maize Yields and Total Production in the U.S. Corn Belt? Field Crops Research, 192, 1-12. https://doi.org/10.1016/j.fcr.2016.04.004

Morita, S., Yonemaru, J., \& Takanashi, J. (2005). Grain Growth and Endosperm Cell Size under High Night Temperatures in Rice (Oryza sativa L.). Annals of Botany, 95, 695-701. https://doi.org/10.1093/aob/mci071

Mourtzinis, S., Rarralino Edreira, J. I., Conley, S. P., \& Grassini, P. (2017). From Grid to Field: Assessing Quality of Gridded Weather Data for Agricultural Applications. European Journal of Agronomy, 82, 163-172. https://doi.org/10.1016/j.eja.2016.10.013

National Climatic Data Center, NCDC (2011). Global Historical Climatology Network-Daily. Asheville, NC: National Oceanic and Aerospace Administration-National Climatic Data Center (NOAA-NCDC). https://www.ncdc.noaa.gov/cdo-web/

Pathak, H., Ladha, J. K., Aggarwal, P. K., Peng, S., Das, S., Singh, Y., Singh, B. S., Kamra, S. K., Mishra, B., Sastri, A. S. R. A. S., Aggarwal, H. P., Das, D. K., \& Gupta, R. K. (2003). Trends of Climatic Potential and On-Farm Yields of Rice and Wheat in the Indo-Gangetic Plains. Field Crops Research, 80, 223-234. https://doi.org/10.1016/S0378-4290(02)00194-6

Peng, S., Huang, J. J., Sheehy, E., Laza, R. C., Visperas, R. M., Zhong, X. G., Centeno, S., Khush, G. S., \& Cassman, K. G. (2004). Rice Yields Decline with Higher Night Temperature from Global Warming. PNAS, 101, 9971-9975. https://doi.org/10.1073/pnas.0403720101

Ray, D. K., Gerber, J. S., MacDonald, K., \& West, P. C. (2015). Climate Variation Explains a Third of Global Crop Yield Variability. Nature Communications, 6, 5989. https://doi.org/10.1038/ncomms6989

Rosenzweig, C., \& Parry, M. L. (1994). Potential Impact of Climate Change on World Food Supply. Nature, 367, 133-138. https://doi.org/10.1038/367133a0

Schiermeier, Q. (2008). Climate Anomaly Is an Artefact. Nature, 453, 569. https://www.nature.com/news/2008/080528/full/453569a.html https://doi.org/10.1038/453569a

SYSTAT (2013). SYSTAT Software Inc. Ver. 13 Manual. San Jose, CA: SYSTAT.

Tamaki, M., Ebata, M., Tashiro, T., \& Ishikawa, M. (1989). Physio-Ecological Studies on Quality Formation of Rice Kernel. Japanese Journal of Crop Science, 58, 695-703. https://doi.org/10.1626/jcs.58.695 
United States Census Bureau, US Census (2011). Population of States and Counties of the United States. Washington DC: US Census Bureau.

United States Department of Agriculture, USDA (2018a). Grain: World Markets and Trade. https://apps.fas.usda.gov/psdonline/circulars/grain.pdf

United States Department of Agriculture, USDA (2018b). Rice Yearbook. https://www.ers.usda.gov/data-products/rice-yearbook/rice-yearbook

United States Department of Agriculture-National Agricultural Statistics Service, USDANASS (2018c). Rice Planted Area. Acres (000) and Change from Previous Year. https://www.nass.usda.gov/Charts and Maps/graphics/riceacm.pdf

United States Department of Agriculture-National Agricultural Statistics Service, USDANASS (2016). Rice.

https://www.nass.usda.gov/Statistics by Subject/index.php?sector=CROPS

Van Wart, J., Grassini, P., \& Cassmann, K. G. (2013). Impact of Derived Global Weather Data on Simulated Crop Yields. Global Change Biology, 19, 3822-3834.

https://doi.org/10.1111/gcb.12302

Wang, H., Schubert, S., Suarez, M., Chen, J., Hoerling, M., Kumar, A., \& Pegion, P. (2009). Attribution of the Seasonality and Regionality in Climate Trends over the United States during 1950-2000. Journal of Climate, 22, 2571-2590.

https://doi.org/10.1175/2008JCLI2359.1

Wheeler, T. R., Craufurd, P. Q., Ellis, R. H., Porter, J. R., \& Vara Prasad, P. V. (2000). Temperature Variability and the Yield of Annual Crops. Agriculture, Ecosystems \& Environment, 82, 159-167. https://doi.org/10.1016/S0167-8809(00)00224-3

Yang, Y., Wilson, L. T., \& Wang, J. (2010). Development of an Automated Climatic Data Scraping, Filtering and Display System. Computers and Electronics in Agriculture, 71, 77-87. https://doi.org/10.1016/j.compag.2009.12.006

Zhang, Y., Tang, Q., Peng, S., Zou, Y., Chen, S., Shi, W., Qin, J., \& Laza, M. R. C. (2013). Effects of High Night Temperature on Yield and Agronomic Traits of Irrigated Rice under Field Chamber System Condition. Australian Journal of Crop Science, 7, 7-13. 